\title{
Predicting Nitrogen Content in the Northern Mixed-Grass Prairie
}

\author{
M. R. Haferkamp, ${ }^{1}$ M. D. MacNeil, ${ }^{2}$ and E. E. Grings ${ }^{3}$ \\ Authors are ${ }^{1}$ Rangeland Scientist, ${ }^{2}$ Research Geneticist, and ${ }^{3}$ Research Animal Scientist, USDA-ARS, \\ Fort Keogh Livestock and Range Research Laboratory, 243 Fort Keogh Road, Miles City, MT 59301-4016.
}

\begin{abstract}
Forage quality and quantity are important factors affecting livestock production from grazing lands. "Greenness" has been proposed as an indicator of herbage quality in semiarid environments, particularly nitrogen $(\mathrm{N})$ content. The objective of this study was to assess the potential of estimating $\mathrm{N}$ content of forage using dead:green ratios and accumulated growing-degreedays (AGDD). Standing crop samples were collected April through October over 3 years from each of 3 replicated grazing regimes on a silty range site in eastern Montana. Samples were sorted into live, current dead, and old dead components, then dried, ground, and analyzed for $\mathrm{N}$ content. The AGDD for base temperature $45^{\circ} \mathrm{F}\left(7.2^{\circ} \mathrm{C}\right)$ was calculated from National Oceanic and Atmospheric Administration (NOAA) reported monthly average temperatures for Miles City. An equation to predict percent $\mathrm{N}$ in the total standing crop from percent dead forage and AGDD was developed using multiple linear regression. This equation accounted for $75.9 \%$ of variation in percent $\mathrm{N}$, and prediction error variance was 0.026 . To validate this equation, data were obtained from samples collected from April through September in an independent study of 8 areas on silty and claypan range sites grazed during autumn and winter. Samples from these sites were treated and analyzed in the same manner as those used to develop the equation. The developed equation was used to predict percent $\mathrm{N}$ for the validation data. The resulting correlation between predicted and actual values was 0.79 . The regression coefficient for actual values on predicted values was $0.995 \pm 0.125$. The intercept did not differ from $0.0(P=0.22)$, and prediction error variance was 0.042 . This equation has utility for predicting $\mathrm{N}$ level of forage from Northern Great Plains rangelands.
\end{abstract}

\section{Resumen}

La cantidad y calidad del forraje son factores importantes que afectan la producción animal en los pastizales. "Verdor" ha sido propuesto como un indicador de la calidad del forraje, particularmente del contenido de nitrógeno (N), en los ambientes semiáridos. El objetivo de este estudio fue evaluar el potencial para estimar el contenido de $\mathrm{N}$ del forraje usando relaciones de forraje muerto:forraje verde y los días-grado-crecimiento acumulados (AGDD). Se colectaron muestras de biomasa en pie de Abril a Octubre durante un periodo de 3 años en 3 regímenes de apacentamiento repetidos 3 veces cada uno, ubicados en un sitio de pastizal aluvial del este de Montana. Las muestras se clasificaron en los siguientes componentes: biomasa viva, biomasa recién muerta y biomasa muerta vieja; posteriormente se molieron y analizaron para determinar el contenido de N. Los díasgrado-crecimiento acumulados, tomando como base $45^{\circ} \mathrm{F}\left(7.2^{\circ} \mathrm{C}\right)$, se calcularon a partir de las temperaturas promedio mensuales de Mile City reportadas por la Administración Nacional Atmosférica y Oceánica (NOAA). Mediante técnicas de regresión múltiple se desarrollo una ecuación para predecir el contenido de $\mathrm{N}$ en la biomasa en pie total a partir del porcentaje de forraje muerto y los AGDD. La ecuación explicó el $75.9 \%$ de la variación del contenido de $\mathrm{N}$ y la varianza del error de predicción fue 0.026. Para validar esta ecuación, se obtuvieron datos de muestras colectadas de Abril a Septiembre en un estudio independiente de 8 áreas en sitios de pastizal de aluviales y arcillosos apacentados durante el otoño e invierno, las muestras de estos sitios fueron tratadas y analizadas de la misma manera que las utilizadas para desarrollar la ecuación. La ecuación desarrollada fue usada para predecir el porcentaje de $\mathrm{N}$ para la validación de los datos. La correlación resultante entre los valores predichos y los valores actuales fue de 0.79 . El coeficiente de regresión para los datos actuales sobre los datos predichos fue $0.995 \pm 0.125$. La intercepción no difirió de $0.0(P=0.22)$ y la varianza del error de predicción fue 0.042 . Esta ecuación tiene utilidad para predecir el nivel de $\mathrm{N}$ del forraje de los pastizales de las Grandes Planicies del Norte.

Key Words: Northern Great Plains, grazing, forage nutritive quality, rangelands, Montana

\section{INTRODUCTION}

The paper is a contribution from the USDA-ARS and Montana Agr. Exp. Sta., Miles City, MT. The USDA-ARS, Northern Plains Area, is an equal opportunity/affirmative action employer, and all agency services are available without discrimination.

Mention of any trade name or proprietary product does not constitute a guarantee or warranty by the authors or USDA-ARS nor does it imply the approval of these products to the exclusion of others.

Correspondence: M. R. Haferkamp, USDA-ARS, Fort Keogh Livestock and Range Research Laboratory, 243 Fort Keogh Road, Miles City, MT 59301-4016. Email: marshall@larrl.ars.usda.gov

Manuscript received 6 January 2004; manuscript accepted 26 September 2004.
Quantity and quality of forage are important factors affecting livestock production from grazing lands. One of the management challenges in a grazing environment is timely implementation of management tactics in response to dynamic changes in forage quality. Forage indicators that provide managers with clues as to the attainment of thresholds of forage quality known to affect animal performance would allow for more costeffective use of resources. 


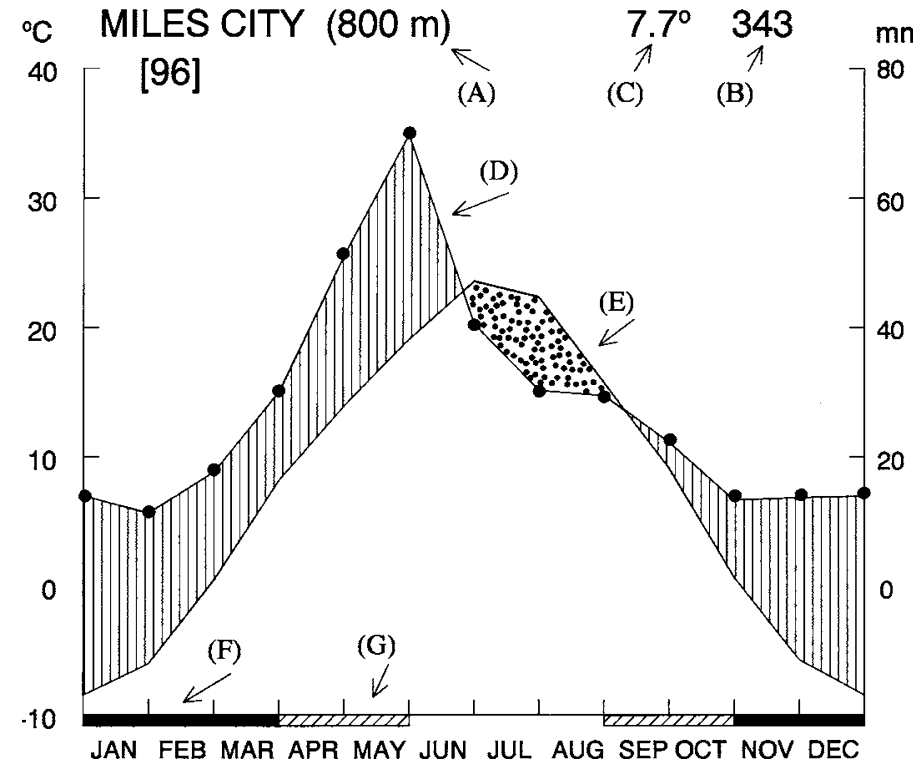

Figure 1. Climate diagram developed for Miles City, Montana, using data from a 96-year period (1900-1996). Included are (A) elevation, (B) mean annual precipitation $(\mathrm{mm}),(\mathrm{C})$ mean annual temperature $\left({ }^{\circ} \mathrm{C}\right),(\mathrm{D})$ mean monthly precipitation $(\mathrm{mm}),(\mathrm{E})$ mean monthly temperature $\left({ }^{\circ} \mathrm{C}\right)$ (F) average monthly minimum temperature less than $0^{\circ} \mathrm{C}$, and $(G)$ absolute monthly minimum temperature less than $0^{\circ} \mathrm{C}$. Data for the area indicate mesic spring, early summer, and autumn periods interrupted by late summer and early autumn drought (stippling). Winter precipitation occurs as snow. Figure follows standard form of Walter (1985).

Crude protein, estimated from percent nitrogen $(\mathrm{N})$ of forage, can be a first limiting nutrient for livestock grazing arid or semiarid rangelands. Nitrogen levels are greatest in metabolically active tissue of plants, which also tends to be greener than less active tissue. "Greenness" has been proposed as an indicator of herbage quality, particularly $\mathrm{N}$ content (Huston and Pinchak 1991; Heitschmidt et al. 1995), with the greenness of a grazing area controlled by plant species composition along with physiologic age and metabolic activity of plant tissue. The level of metabolic activity within plants is, in turn, affected largely by environment (Angell et al. 1990; Huston and Pinchak 1991; DelCurto et al. 1999; Ganskopp and Bohnert 2001) and, to some degree, grazing management (Heitschmidt et al. 1987; Angell et al. 1990). Greenness alone can give an indication of the relative value of forage. Green tissue is of "high" quality and brown tissue of "low" quality. A more specific indication of actual $\mathrm{N}$ content is needed to develop supplementation programs that more specifically match livestock needs at a given point in time. Environment has an impact on metabolic activity, and the addition of environmental condition data to models estimating forage quality is logical.

Frank and Hofmann (1989) stressed that rate of phenological development of grasses growing in the Northern Great Plains is controlled mostly by air temperature. A regression analysis conducted by Frank et al. (1985) revealed a strong linear relationship between phenological development and accumulated heat units or growing-degree-days (AGDD) for western wheatgrass (Pascopyrum smithii [Rydb.] A. Love). Crude protein was predicted from AGDD with an $r$ of 0.91 when used to predict quality of western wheatgrass and crested wheatgrass (Agropyron desertorum [Fisch.] Schult) grown in controlled environments.

A model predicting forage quality from variables easily measured by an individual, such as daily temperatures and relative greenness of forage as estimated by dead:green ratios of clipped standing crop, would aid livestock producers in developing nutritional tactics relative to current forage conditions. The objective of this research was to assess the potential for estimating $\mathrm{N}$ content of rangeland forage using dead:green ratio and AGDD. This procedure was validated using independent data.

\section{Study Area}

\section{METHODS}

Research was conducted at the Fort Keogh Livestock and Range Research Laboratory (lat $46^{\circ} 22^{\prime} \mathrm{N}$, long $105^{\circ} 5^{\prime} \mathrm{W}$ ) near Miles City, Montana. Regional topography varies from rolling hills to broken badlands with small ephemeral streams flowing into rivers in broad, nearly level valleys and is representative of the semiarid mixed-grass prairie of the Northern Great Plains. Indigenous vegetation on the 22500 -ha research station is a grama-needlegrass-wheatgrass (Bouteloua-Stipa-Agropyron) mix (Küchler 1964). Annual precipitation averages $343 \mathrm{~mm}$, with about $60 \%$ received from April through September (Fig. 1). Daily temperatures can range from $>38^{\circ} \mathrm{C}$ during summer to $<-40^{\circ} \mathrm{C}$ during winter. The average frost-free growing season is 150 days. The region also frequently experiences periods of below-average precipitation (Hurtt 1951; Reed and Peterson 1961; Olson et al. 1985). Elevation at the study site was $719 \mathrm{~m}$ and NOAA weather station $800 \mathrm{~m}$.

The 1-ha baseline study area was a nearly level silty range site. Soil was an Eapa series (fine-loamy, mixed, superactive, frigid Aridic Argiustoll). Vegetation was characterized by a C3 annual grass, Japanese brome (Bromus japonicus Thunb.); C3 perennial grasses, prairie Junegrass (Koeleria macrantha [Ledeb.] J.A.), needleandthread (Hesperostipa comata [Trin. \& Rupr.] Barkworth), and western wheatgrass; a C3 sedge, thread-leaf sedge (Carex filifolia Nutt.); C4 perennial grasses, blue grama (Bouteloua gracilis [Willd. ex Kunth] Lag. ex Griffiths) and red threeawn (Aristida purpurea Nutt. var. longiseta [Steud.] Vasey); succulent, prickly pear (Opuntia sp.); half-shrubs, fringed sagewort (Artemisia frigida Willd), common sagewort (A. campestris L.), and phlox (Phlox hoodii Richards); and forbs, western salsify (Tragopogon dubius Scop.) and hairy goldaster (Heterotheca villosa [Pursh.] Shinners var. villosa). Perennial cool-season grasses and sedges generally made up greater than $60 \%$ of the green standing crop during April through July each year. Perennial warm-season grasses and sageworts became more obvious during July.

\section{Environment}

Long-term and current precipitation and temperature records were obtained from a weather station located at Frank Wiley Field, Miles City, Montana, at 800-m elevation, $12.5 \mathrm{~km}$ from the study site (NOAA 1991-1998) or from a study area located within $6 \mathrm{~km}$ (Haferkamp and MacNeil 2004). Growing-degreedays for base temperature $45^{\circ} \mathrm{F}\left(7.2^{\circ} \mathrm{C}\right)$ were calculated with the following equation ( $\{[$ (average maximum monthly temperature + average minimum monthly temperature)/2] -45$\} \cdot$ number 
of days in the month) for each month from April through October. Growing-degree-days were then summed from April through October (Table 1).

Amount and distribution of precipitation varied during the 3 years of baseline study (Haferkamp and MacNeil 2004). Precipitation was above average during January, March, May, October, and November 1996; April and July 1997; and March, June, July, August, and October 1998. Although May 1996 was very wet, precipitation was below average thereafter until the following October. Precipitation was below average in May and June 1997 and from August 1997 through February 1998. April and May were dry in 1998, but rainfall was above average the remainder of the summer. Average monthly temperatures were near normal during all 3 years.

\section{Treatments in Baseline Study}

Forage samples used to develop the regression equation in the baseline study came from an experiment that included 3 treatments imposed on replicated plots. Treatments were no grazing (control), intensively grazed by sheep in mid-May (May), and intensively grazed by sheep in mid-July (July) (Haferkamp and MacNeil 2004). Treatments were arranged in a randomized complete block design with 4 blocks of 3 treatment plots $(15 \times 15 \mathrm{~m})$. The study was conducted during 1996, 1997, and 1998. Sheep (28-35 head) grazing was used to remove $60 \%-75 \%$ of herbage (by weight). This was generally attained with a single 3-hour-long grazing bout.

Grazing actually reduced live aboveground biomass by $68 \%-78 \%$ during both May and July. Standing current dead (i.e. this year's senesced herbage) was similar before and after grazing in May but was reduced $56 \%-71 \%$ by grazing in July. Standing old dead (i.e. previous year's senesced herbage) was reduced $65 \%$ when averaged across years.

\section{Collection and Chemical Analysis of Baseline Samples}

Seasonal effects of grazing and environment on biomass were measured from mid-April to mid-October (weather permitting) at about 30-day intervals each year. As with the application of grazing treatments, 2 blocks were sampled during the same week during each 30-day period.

Aboveground Biomass. On each sample date, standing crop was clipped to ground level and sorted by plant species, within $10.25-\mathrm{m}^{2}$ quadrat $(50 \times 50 \mathrm{~cm})$ randomly located within each replication. The standing crop sample was refrigerated and sorted into live, current standing dead, and old standing dead tissue within 24 hours of collection. Complete separation of live and current dead portions was attained by clipping these components from each leaf and stem. Samples were dried at $60^{\circ} \mathrm{C}$ for 48 hours and ground for laboratory analyses. Samples were ground to pass through a $1-\mathrm{mm}$ mesh screen in a Wiley mill and then further reduced to pass a 100mesh screen by grinding for 24 hours with a roller mill (Mortenson 2003).

Laboratory Analyses. Ground samples were dried again at $60^{\circ} \mathrm{C}$ for 16 hours before weighing for chemical analyses. Plant samples were analyzed for total $\mathrm{N}$ with a Carlo/Erba automated dry combustion analyzer. Results are presented on a $105^{\circ} \mathrm{C}$ dry-matter basis.
Table 1. Accumulated growing-degree-days for base temperature $45^{\circ} \mathrm{F}\left(7.2^{\circ} \mathrm{C}\right)$ derived for $1996-1998$ for Miles City, Montana.

\begin{tabular}{lrrr}
\hline Month & 1996 & 1997 & 1998 \\
\hline April & 42 & 0 & 183 \\
May & 244 & 366 & 620 \\
June & 952 & 1155 & 1082 \\
July & 1817 & 2014 & 2111 \\
August & 2769 & 2894 & 3106 \\
September & 3213 & 3533 & 3838 \\
October & 3253 & 3673 & 3971 \\
\hline
\end{tabular}

\section{Equation Development and Validation}

An equation to predict percent $\mathrm{N}$ was developed using percent dead (current dead + old dead) collected from each block-bytreatment subclass at each time point and AGDD (Table 1). Visual inspection of the graphs of $\mathrm{N}$ content versus percent dead and AGDD suggested that linear models were appropriate, and deviation from straight-line forms could be adequately accounted for with quadratic terms. Backward elimination procedures were used to remove unnecessary effects from the model. Thus, the final model was

$\% N=a+b_{1} d+b_{2} d^{2}+b_{3} n+b_{4} n^{2}+b_{5} d n+b_{6} d^{2} n+b_{7} d n^{2}+e$

with

$\% \mathrm{~N}$ being the $\mathrm{N}$ content of forage sampled from a block by treatment combination on a given date;

a being the intercept of the regression equation that may be interpreted as the predicted $\% \mathrm{~N}$ if degree-day and percent dead were both zero;

$b_{1}-b_{7}$ being regression coefficients to be estimated from the data;

$\mathrm{d}$ being the growing-degree-days accumulated to that date in the year;

$\mathrm{n}$ being the percent dead plant material from a given block-bytreatment combination on a given date; and

e being the residual deviation of predicted values from observed values (error).

The predictive equation was validated using data for April through September from an independent study (Heitschmidt et al. 1995) of 8 areas on silty and clay-pan range sites grazed during autumn and winter. Samples from these sites had been separated into live and dead components and percent $\mathrm{N}$ determined. In this study, precipitation was well above average in 1991 and near normal in 1992. The climatic conditions for the 2 years provided an exceptional growing year in 1991 and an average to slightly above-average year in 1992. Standing crop in the Heitschmidt et al. (1995) study, however, contained a greater component of annual grasses than samples used to develop the model (Haferkamp and MacNeil 2004).

\section{RESULTS}

Grazing treatments applied in this study and the dynamic environmental conditions encountered during the 3 years provided a wide range in biomass production and forage quality. 


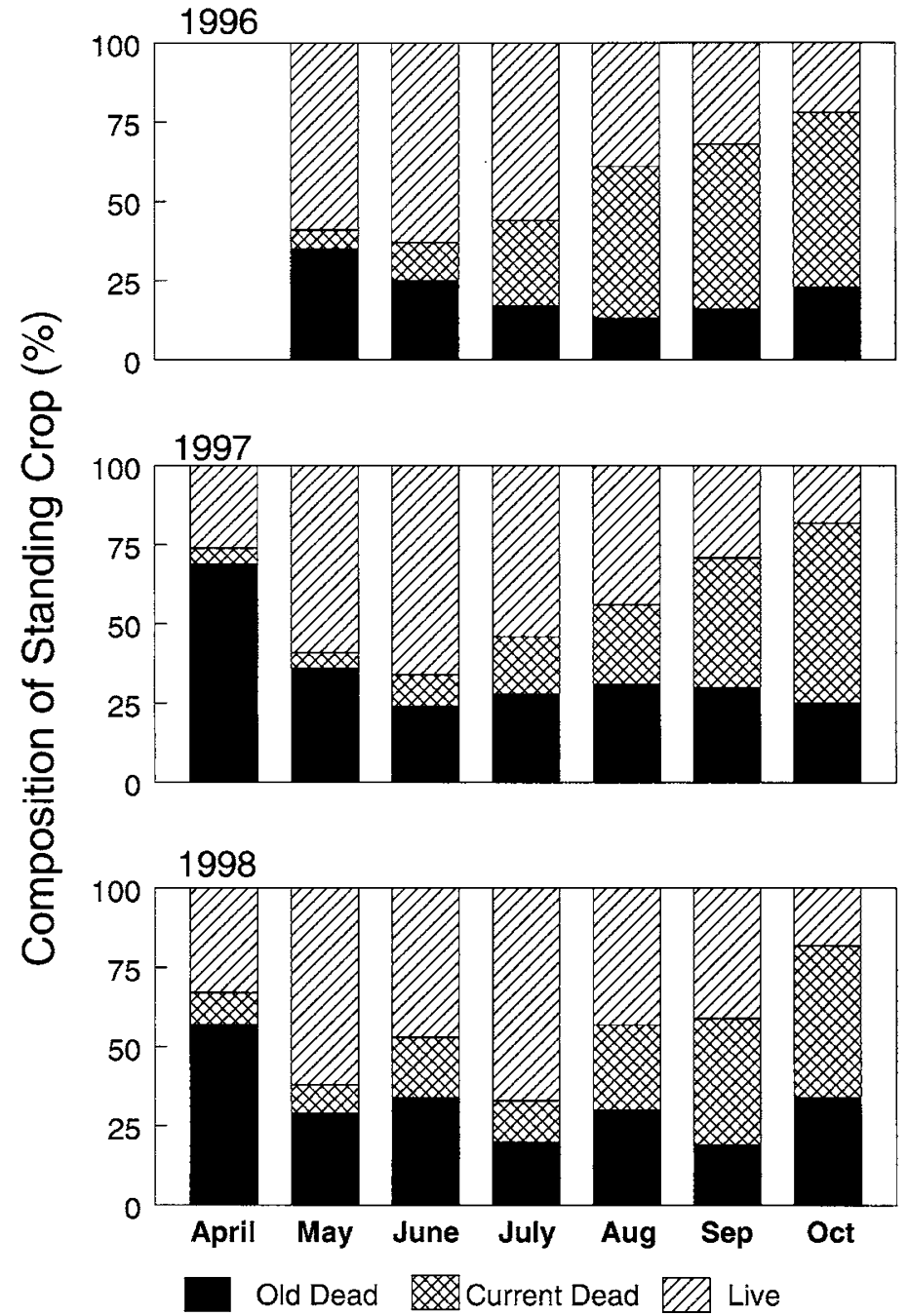

Figure 2. Percent composition for live, current dead, and old dead in the standing crop samples used to develop the regression equation. These are based on least square means from Haferkamp and MacNeil (2004). Standard error of the mean for old dead $=3.0$, current dead $=$ 2.5 , and live $=3.3$. The month-within-year interaction was significant for all components $(P<0.05)$.

\section{Baseline Data}

Aboveground Biomass. Standing crops across years and treatments were $66 \pm 24 \mathrm{~g} \cdot \mathrm{m}^{-2}$ (mean \pm error mean square) for total, $29 \pm 15 \mathrm{~g} \cdot \mathrm{m}^{-2}$ for live, $15 \pm 7 \mathrm{~g} \cdot \mathrm{m}^{-2}$ for current dead, and $21 \pm 12 \mathrm{~g} \cdot \mathrm{m}^{-2}$ for old dead. Percent live peaked in May, June, or July, depending on the year (Fig. 2). Percent current dead + old dead was greatest in spring and autumn (Fig. 2). Percent current dead increased as the growing season progressed, whereas the old dead was greatest in spring and gradually decreased through time.

Forage Quality. Forage percent $\mathrm{N}$ was greatest in spring and early summer and decreased as plants matured and environmental stress increased (Table 2). Slightly higher spring forage $\mathrm{N}$ values that occurred in May- and July-grazed plots compared to controls reflect reduction in the old dead component by grazing and perhaps trampling. Regrowth of May-grazed plots
Table 2. Mean percent $\mathrm{N}$ in total aboveground biomass for the significant month-within-year by treatment interaction. Standard error of the mean $=0.08$. Data from samples collected in a study conducted at Miles City, Montana, during 1996-1998 and reported by Haferkamp and MacNeil (2004).

\begin{tabular}{lccccccc}
\hline & April & May & June & July & August & September & October \\
\cline { 3 - 8 } Year/Treatment & & \multicolumn{7}{c}{$(\% \mathrm{~N})$} \\
\hline 1996 & & & & & & \\
$\quad$ Control & - & 1.73 & 1.38 & 1.00 & 0.86 & 0.73 & 0.75 \\
May Grazed & - & - & 1.47 & 1.15 & 0.89 & 0.67 & 0.80 \\
July Grazed & - & - & - & - & 0.87 & 0.62 & 0.93 \\
1997 & & & & & & & \\
Control & 1.02 & 1.23 & 1.16 & 1.10 & 0.87 & 0.86 & 0.88 \\
May Grazed & 1.23 & 1.39 & 1.60 & 1.32 & 1.06 & 0.87 & 0.91 \\
$\quad$ July Grazed & 1.43 & 1.70 & 1.33 & 1.11 & 0.98 & 0.95 & 0.76 \\
1998 & & & & & & & \\
Control & 1.22 & 1.42 & 1.13 & 1.27 & 1.20 & 1.18 & 0.92 \\
May Grazed & 1.32 & 1.54 & 1.33 & 1.62 & 1.41 & 1.19 & 1.07 \\
July Grazed & 1.94 & 1.72 & 1.18 & 1.34 & 1.23 & 1.15 & 1.22 \\
\hline
\end{tabular}

generally provided greater percent $\mathrm{N}$ in June and July compared to controls and July-grazed plots.

\section{Equation Development and Validation}

In the baseline study, $\mathrm{N}$ of the total forage sample averaged $1.17 \%$, AGDD averaged 2127 , and dead averaged $57.1 \%$. Table 3 presents statistics describing the equation to predict percent $\mathrm{N}$ from percent dead and AGDD. All independent variables contained in the equation, except the linear effect of percent dead, were significant. Separately, the independent variables explained only $3 \%$ or less of the variation in percent N. However, collectively the model accounted for $75.9 \%$ of variation in percent $\mathrm{N}$, and the prediction error variance was 0.026 . The seeming disparity between variation accounted for by each of the independent variables and the model results from the colinearity among independent variables.

The equation developed from the baseline grazing study when used to predict percent $\mathrm{N}$ in the validation study samples with the resulting correlation between predicted and actual values being 0.79 . Regression of actual values on predicted values was $0.995 \pm 0.125$ with a zero intercept $(P=0.22)$ (Fig. 3). Prediction error variance was 0.042 .

\section{DISCUSSION}

The rangeland forage resources from which data were used in this research were heterogeneous with respect to species composition. Variation among individual species in phenological development and senescence with respect to AGDD was anticipated (Frank and Hofmann 1989; Huston and Pinchak 1991; Ganskopp and Bohnert 2001; Clark 2003). Additionally, the relationship between forage quality and time has been shown to be nonlinear across a growing season (Adams and Short 1988; Frank and Karn 1989; Aiken 1997). These factors likely 
Table 3. Summary statistics for prediction of percent $\mathrm{N}$ from accumulated growing-degree-days and percent dead.

\begin{tabular}{lcccc}
\hline $\begin{array}{l}\text { Independent } \\
\text { Variable }\end{array}$ & $\begin{array}{c}\text { Regression } \\
\text { Coefficient }\end{array}$ & $\begin{array}{c}\text { Standard } \\
\text { Error }\end{array}$ & $\begin{array}{c}\text { Standard } \\
\text { Partial } \\
\text { Regression }\end{array}$ & Probability \\
\hline Intercept & $22.15 \times 10^{-3}$ & $1.55 \times 10^{-3}$ & 6.85 & $<0.001$ \\
Degree-days (d) & $-5.07 \times 10^{-6}$ & $1.29 \times 10^{-6}$ & -2.09 & $<0.001$ \\
$\mathrm{~d}^{2}$ & $0.18 \times 10^{-8}$ & $0.37 \times 10^{-9}$ & 2.98 & $<0.001$ \\
$\%$ Dead (n) & $-56.38 \times 10^{-4}$ & $53.51 \times 10^{-4}$ & -0.35 & 0.293 \\
$\mathrm{n}^{2}$ & $-93.68 \times 10^{-4}$ & $46.12 \times 10^{-4}$ & -0.69 & 0.043 \\
$\mathrm{~d} \cdot \mathrm{n}$ & $-5.52 \times 10^{-6}$ & $2.79 \times 10^{-6}$ & -1.86 & 0.050 \\
$\mathrm{~d}^{2} \cdot \mathrm{n}$ & $0.13 \times 10^{-8}$ & $0.58 \times 10^{-9}$ & -1.74 & 0.026 \\
$\mathrm{~d} \cdot \mathrm{n}^{2}$ & $9.50 \times 10^{-6}$ & $2.01 \times 10^{-6}$ & 2.84 & $<0.001$ \\
\hline
\end{tabular}

${ }^{1}$ Snedecor and Cochran (1967).

contribute to the significance of quadratic and interactive terms in the prediction of percent $\mathrm{N}$ from AGDD and percent dead.

Estimation of percent $\mathrm{N}$ by this method requires 1) collection of forage samples, 2) separation into live and dead components, 3) drying and weighing the components, 4) derivation of AGDD as described, and 5) application of the equation. Precise separation of live from dead may not be necessary. The equation appeared to effectively predict percent $\mathrm{N}$ in the validation study forage samples. In those samples, a leaf or stem was counted as green if over one-half was green and as current dead if over one-half was dead.

Justification for the regression method of determining percent $\mathrm{N}$ seems logical because phenological development of plants follows a similar pattern regardless of vegetative region (Frank and Hofmann 1989; Ganskopp and Bohnert 2001), and the rate of this development is controlled mostly by temperature (Frank and Hofmann 1989). Most herbaceous plants, especially C3 species, in the Northern Great Plains actively grow during late spring and early summer, and an average of $90 \%$ of the year's perennial cool-season grass production and $75 \%$ of the perennial warm-season grass production is completed by the end of June (R. K. Heitschmidt, unpublished file data, USDA-ARS, Miles City, MT, 2003). In the Northern Great Plains, the live component tends to peak in early summer. Current dead tends to increase as the growing season progresses, and plant parts senesce with maturity and/or in response to environmental stress. The old dead component that is carried over from the previous year's crop is greatest in spring and decreases through the growing season (Singh et al. 1983; Heitschmidt et al. 1995).

Quality of forage generally tracks seasonal development of the dominant plant species (Huston and Pinchak 1991; Heitschmidt et al. 1995; Ganskopp and Bohnert 2001; Clark 2003). Many phenomena can affect the nutritive quality and the indicative dead:green ratio of the standing crop. Forage quality may increase following precipitation events that promote plant growth, but it may also decrease prematurely when an abundance of annual grasses mature and senesce earlier in the growing season than perennial plants (Haferkamp et al. 1994; Heitschmidt et al. 1995). The onset of a dry period that restricts soil water can either increase or decrease forage quality (Huston and Pinchak 1991). Soil water restriction during

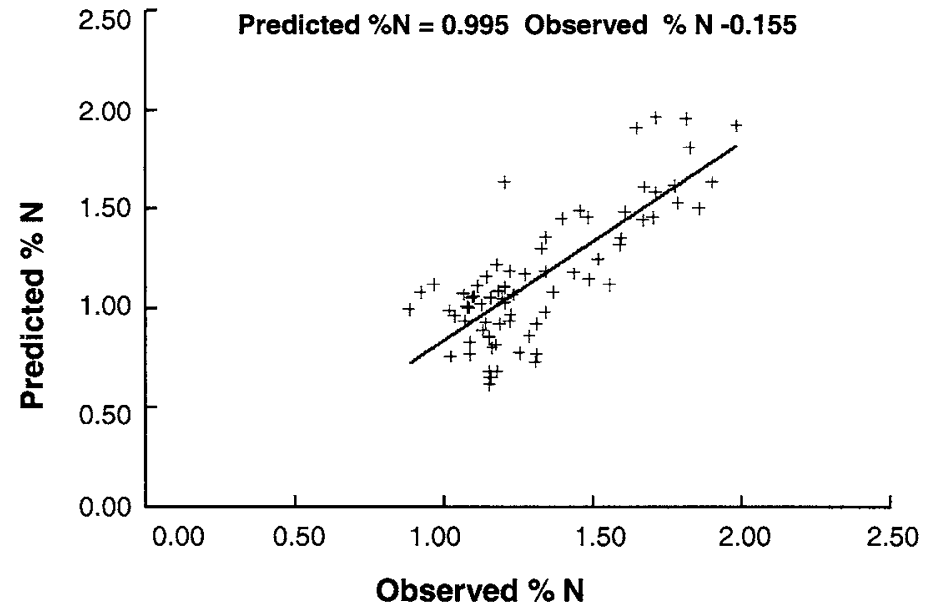

Figure 3. Scatter plot and linear regression of predicted on observed percent N from the validation study (Heitschmidt et al. 1995).

vegetative growth may only slow growth and maintain forage quality, but during severe water stress with increased senescence, forage quality may decline because of translocation of nutrients to belowground organs. Factors such as low ambient temperature or ample soil water that often delay plant maturation but sustain metabolic activity can maintain or even enhance forage quality. However, despite the numerous factors that either directly or indirectly affect forage nutritive value, the combination of AGDD and percent dead was sufficient to predict $\mathrm{N}$ content.

We acknowledge that livestock may select a higher-quality diet than is represented by clipped forage samples (Weir and Torell 1959; Huston and Pinchak 1991; Schlegel et al. 2000). However, the prediction equation has promise for the rapid estimation of forage quality on Northern Great Plains rangelands. Although the equation effectively validated data derived from a different study, the utility of the relationship needs to be established in other locations. This procedure could easily be conducted by a single individual. Temperature information needed to calculate growing-degree-days can be obtained by the use of a maximum-minimum thermometer or access to online weather information. Other supplies needed would include scissors or gardening shears for clipping and a small scale, such as a kitchen scale, for weighing live-dead components. Samples could be air dried or dried using available ovens. Percent $\mathrm{N}$ can be calculated from the regression equation using a hand calculator or computer spreadsheet.

\section{ACKNOWLEDGMENTS}

The authors express appreciation to personnel of USDA-ARS and Montana Agricultural Experiment Station located at Fort Keogh Livestock and Range Research Laboratory for their diligent efforts in helping carry out this research.

\section{LITERATURE CITED}

Adams, D. C., And R. E. Short. 1988. The role of animal nutrition on productivity in a range environment. In: R. S. White and R. E. Short [eds.]. Achieving efficient 
use of rangeland resources. Proceedings Fort Keogh Research Symposium; September 1987; Miles City, MT. p 37-43.

AIKEN, G. E. 1997. Temporal effects on steer performance and nutritive values for eastern gamagrass grazed continuously for different durations. Journal of Animal Science 75:803-808.

Angell, R. F., R. F. Millek, and M. R. Haferkamp. 1990. Variability of crude protein in crested wheatgrass at defined stages of phenology. Journal of Range Management 43:186-189.

CLARK, P. E. 2003. Date and plant community effects on elk sedge forage quality. Journal of Range Management 56:21-26.

DelCurto, T., B. W. Hess, J. E. Huston, and K. C. Olson. 1999. Optimum supplementation strategies for beef cattle consuming low-quality roughages in the western United States. Proceedings American Society of Animal Science. Available at: http://www.asas.org/jas/symposium/proceedings/ 0922.pdf. Accessed 18 September 2003.

Frank, A. B., J. D. Berdahl, and R. E. Barker. 1985. Morphological development and water use in clonal lines of four forage grasses. Crop Science 25:339-344.

Frank, A. B., AND L. Hofmann. 1989. Relationship among grazing management, growing degree days, and morphological development for native grasses on the Northern Great Plains. Journal of Range Management 42:199-202.

Frank, A. B., and J. F. Karn. 1989. Prediction of digestibility and protein from growing degree-days for crested wheatgrass and western wheatgrass. In: Proceedings of XVI International Grassland Congress; 4-11 October 1989; Nice, France. p 925-926.

Ganskopp, D., AND D. Bohnert. 2001. Nutritional dynamics of 7 northern Great Basin grasses. Journal of Range Management 54:640-647.

Haferkamp, M. R., and M. D. MacNell. 2004. Grazing effects on carbon dynamics in the northern mixed-grass prairie. Environmental Management 33(Suppl 1): S462-S474. D0I: 10.1007/s00267-003-9154-x. Available at: http://www. springerlink.com/media/PGWF2MWGUPCUXAYLWA7W/Contributions/T/4/8/ R/T48RTF27CHAY7KQF.pdf. Accessed 29 September 2004.

Haferkamp, M. R., J. A. Young, E. E. Grings, M. G. Karl, R. K. Heitschmidt, and M. D. MacNeIL. 1994. Japanese brome in the Northern Great Plains. In: S. B. Monsen and S. G. Kitchen [comps.]. Proceedings-Symposium: Ecology and Management of Annual Rangelands; USFS-Intermountain Research Station, Ogden, UT. General Technical Report INT GTR-313. p 396-401.

Heitschmidt, R. K., S. L. Dowhower, and J. W. Walker. 1987. Some effects of a rotational grazing treatment on quantity and quality of available forage and amount of ground litter. Journal of Range Management 40:318-321.
Heitschmidt, R. K., E. E. Grings, M. R. Haferkamp, and M. G. Karl. 1995. Herbage dynamics on 2 Northern Great Plains range sites. Journal of Range Management 48:211-217.

HURTT, L. C. 1951. Managing Northern Great Plains ranges to minimize the effects of drought. USDA Circular 865. $24 \mathrm{p}$.

Huston, J. E., and W. E. Pinchak. 1991. Range animal nutrition. In: R. K. Heitschmidt and J. W. Stuth [eds.]. Grazing management: An ecological perspective. Corvallis, OR: Timber Press. p 27-63.

KüCHLER, A. W. 1964. Potential natural vegetation of the conterminous United States. American Geographic Society Special Publication 36. New York, NY: American Geographic Society. $77 \mathrm{p}$.

Mortenson, M. C. 2003. Effects of interseeded alfalfa (Medicago sativa ssp. falcata) on forage production, forage quality, and carbon sequestration on a mixed-grass rangeland [thesis]. Laramie, WY: University of Wyoming. $59 \mathrm{p}$.

National Oceanic and Atmospheric Administration (NOAA). 1991-1998. Climatological data annual summary, Montana. 13:99-101. Asheville, NC: National Climatic Data Center.

OLson, K. C., R. S. White, And B. W. Sindelar. 1985. Response of vegetation of the Northern Great Plains to precipitation amount and grazing intensity. Journal of Range Management 38:357-361.

Reed, M. J., and R. A. Peterson. 1961. Vegetation, soil, and cattle responses to grazing on Northern Great Plains Range. USDA Tech. Bull. 1252. 79 p.

Schlegel, M. L., C. J. Wachenheim, M. E. Benson, N. K. Ames, and S. R. Rust. 2000. Grazing methods and stocking rates for direct seeded alfalfa pastures: II. Pasture quality and diet selection. Journal of Animal Science 78:22022208.

Singh, J. S., W. K. Lauenroth, R. K. Heitschmidt, and J. L. Dodd. 1983. Structural and functional attributes of the vegetation of northern mixed prairie of North America. Botanical Review 49:117-149.

Snedecor, G. W., and W. G. Cochran. 1967. Statistical methods. 6th ed. Ames, IA: lowa State University Press. 593 p.

Walter, H. 1985. Vegetation of the earth and ecological systems of the geobiosphere. 3rd ed. (translated from the 5th, revised German edition by 0. Muise). New York, NY: Springer-Verlag. 527 p.

WeIR, W. C., AND D. T. Torell. 1959. Selective grazing by sheep as shown by a comparison of the chemical composition of range and pasture forage obtained by hand clipping and that collected by esophageal-fistulated sheep. Journal of Animal Science 18:641-649. 